\title{
Pre-extension Demonstration and Evaluation of Engine Driven Sorghum Thrasher Technology in the Selected AGP-II Districts of Harari region and Dire Dawa Administration
}

\author{
Abdulaziz Teha * Tekalign Bedada Jamal Nur Ibsa Aliyi Kibrat Ketema \\ Oromia Agricultural Research Institute, Fedis Agricultural Research Centre, \\ P.O. Box 904, Harar, Ethiopia
}

\begin{abstract}
An engine driven sorghum thresher was designed and developed in Fedis Agricultural Research Center with a view to increase the threshing efficiency, threshing capacity and to reduce the cost of threshing in comparison with traditional methods of threshing sorghum crop. The machine was demonstrated in Harari Region and Dire Dawa administration council. The result indicated that the average efficiency, output capacity were 88.97 to $97.08 \%, 6$ to $8.36 \mathrm{qt} /$ ha and grain damage less than $1 \%$.Sorghum is also the most widely cultivated and consumed cereals in Ethiopia. According to (CSA, 2008), it ranks third after maize and tef in total production, after maize in yield per hectare and after tef and maize in area harvested. Currently sorghum is produced by 5million holders and its production is estimated to be 4 million metric tons from nearly 2 million hectares of land giving the national average grain yield of around 2 tons per hectares (CSA, 2012). In fact sorghum is not only drought-resistant, it can also withstand periods of water logging (Taylor, 2010).Hence Fadis Agricultural Research Center developed complete sorghum threshing machine and demonstrate to overcome sorghum threshing challenges such as beating with stick, moving tractor on sorghum as it take longtime, consume human energy consuming, hardly detach the grain from sorghum head, thereby decreasing tremendous sorghum grain post-harvest loss because of traditional threshing method
\end{abstract}

Keywords: Sorghum Thrasher, Engine driven, Demonstration, Harari and Dire Dawa

DOI: $10.7176 / F S Q M / 97-05$

Publication date:May $31^{\text {st }} 2020$

\section{Introduction}

Sorghum, Sorghum bicolor (L) Moench, is the fifth most important cereal after rice, wheat, maize, and barley. It constitutes the main food grain for over 750 million people who live in the semi-arid tropics of Africa, Asia, and Latin America. The largest group of producers are small-scale subsistence farmers with minimal access to production inputs such as fertilizer(s), pesticides, improved seeds (hybrids or varieties), good soil and water and improved credit facilities for their purchase(FAO,2010).

In rural Africa, threshing involves beating the dried sorghum panicles with sticks on the ground or in sacks, or using a mortar and pestle. Grain is separated from dirt and chaff by winnowing. The time required for threshing depends on variety, the degree of dryness of the grain, and the method of threshing. In some places in India, a common practice for threshing the grain is to place it on the road for vehicles to run over (Simonyan, 2006). A motorized stationary sorghum thresher was developed and tested. The sorghum thresher had the following components: frame, hopper, and threshing unit, sieve, reciprocating mechanism, blower and the collecting trays. The performance variables investigated were: threshing efficiency, cleaning efficiency and cleaning loss (Simonyan, 2009). ). The improved small-engine driven sorghum thresher was designed and produced at Fadis Agricultural Research Center with an intention to solve critical threshing problem of farmers consecutively reducing cost of threshing, labor power and grain loss (Tekalign, 2018) Hence, this activity is aimed at demonstrating and evaluate engine driven Sorghum thrasher technology to the target area

\section{Objectives}

To demonstrate and evaluate engine driven Sorghum Thrasher technology.

To create awareness among farmers, developmental agents, subject matter specialists and other participant stakeholders on engine driven Sorghum Thrasher technology.

To build farmers' knowledge and skill of production and management of the enterprise

To strengthen linkage among stakeholders

\section{Materials and Methods}

Description of the study area

Pre-extension demonstration of sorghum thrasher technology was conducted in Agricultural growth program-II nationally selected districts of Harari region and Dire Dawa administration council. Harari regional state is located on distance of $526 \mathrm{kms}$ from capital city Finfine in direction of country's eastern part; it is all in all bordered by 
Oromia region and hosts one capital town of Oromia Regional state's zone that is East Hararghe. The climatic condition of the region includes highland, midland and lowland; the soil type exist in the region is different in different ecologies of the region that is clay, loam, sandy and black types. Dire Dawa Administration is located on distance of $515 \mathrm{kms}$ from capital city Finfine in direction of county's Eastern part; it is bordered by Somali, and Oromia regions in all directions. Dire Dawa Administration has both urban and rural set governance system. The climatic condition of Dire Dawa is almost dry land with the maximum and minimum temperature $38^{0 \mathrm{c}}$ and $25^{0 \mathrm{c}}$ respectively (EBC broadcasting on metrology allocated time). The selected districts are where the potentiality of the program was succeeded in consideration of residents' problems, potential succession of the technologies these fit problems and solve; including the outcomes prevailed in AGP-I.

\section{Site and farmers selection}

Dire Dawa administration and Harari Regional District were purposively selected by AGP-II nationally. PAs were selected purposively based on the potentiality, appropriateness of the area by considering lodging, slop's land escape, access to road, suit for repeatable monitoring and evaluation in progress of sowing to harvesting. One District from Harari Region (Sofi) and one district from Dire Dawa Administration Bishan Bahe selected. Farmers were selected purposively based on their interest, innovation he/she has, land provision for this pre-extension demonstration, interest in cost-sharing, willingness to share experiences for other farmers, and studying their profile with the participation of DAs and community leaders. The selected farmers were grouped in the form of Farmers Research Group (FRG) with the member of 40 farmers per PAs in consideration of gender issues (women, men and youth). In the study areas total of 4 FRGs (2FRG/ PAs- from one PA 20 farmers and totally 80 farmers were grouped in 4 FRG).

\begin{tabular}{lllll}
\hline District & PAs & Number of trial farmers & Male & Female \\
\hline Dire Dawa & Bishan Bahe & 40 & 30 & 10 \\
Harari & Sofi & 40 & 30 & 10 \\
\hline
\end{tabular}

\section{Data Collection}

Quantitative data Output capacity (qt/h), shelling efficiency (\%), grain damage (\%),number of farmers participated in FRG, number of stakeholders participated on the training and qualitative data were collected through personal field observation, individual interview, Focus Group Discussion by using checklist and data sheet tools. While qualitative data were farmers' perceptions towards the new technology and ranked using pair wise ranking and Matrix ranking.

\section{Data analysis}

Quantitative data was summarized using simple descriptive statistics (Mean, Frequency and Percentage) while the qualitative data collected using group discussion and field observation and oral histories was analyzed using narrative explanation. Finally, data from different sources was triangulated to get reliable information.

\section{Results and Discussion}

\section{Training of farmers and other stalk holders}

Multidisciplinary research team; crop, extension and socio-economic research team and other stakeholders (Offices of Agriculture and Natural Resource) actively participated by sharing their experience and knowledge and journalists for the sake of publicity of the work done Development agents, experts and farmers were participated on the training sorghum thrasher technology and management, post-harvest handling.

Table 2: Type of profession and number of participants during the training at the two Districts, 2018/19

\begin{tabular}{lllllll}
\hline & & \multicolumn{2}{c}{ Kile } & \multicolumn{5}{c}{ Bishan Bahe } & Total \\
\cline { 3 - 6 } No. & Participants & Male & Female & Male & Female & 150 \\
\hline 1 & Farmers & 35 & 20 & 60 & 35 & 12 \\
3 & DAs & 7 & - & 5 & - & 10 \\
4 & District experts & 4 & 1 & 5 & - & 6 \\
\hline & Journalist & 3 & - & 3 & 35 & 178 \\
\hline
\end{tabular}

Among the training participant stakeholders, $84.2 \%$ were farmers. From those farmers, 36.6\% are female farmers' participant. Different extension materials were utilized and distributed for the participants. For those individuals, 50 leaflets and 30 small manuals on the technology that are organized in Afaan Oromoo and English languages were distributed. During the training different questions, opinions and suggestions were raised and reacted from the concerned bodies. Most farmers showed high interest towards the technology .Therefore, all concerned bodies were shared their responsibility for the future intervention and wider reach out of the technology. 
Table 3: The performance of engine driven sorghum thrasher machine

\begin{tabular}{lll}
\hline Descriptions & & Dimension \\
\hline Over all dimensions & Length $(\mathrm{mm})$ & 1340 \\
& Width $(\mathrm{mm})$ & 840 \\
& Height $(\mathrm{mm})$ & 1130 \\
$\begin{array}{l}\text { Power source } \\
\text { Power requirement(HP) }\end{array}$ & & Honda engine \\
Fuel consumption(lit/qt) & & 5 \\
Drum concave clearance & Inlet (mm) & $0.096-0.103$ \\
& & 23 \\
Recommended drum speed(RPM) & Out let (mm) & 10 \\
Performance of the machine & Output capacity (qt/h) & $700-900$ \\
& $6-8.36$ & $6-8.36$ \\
& Threshing efficiency (\%) & 88.97 to $97.08 \%$ \\
\hline
\end{tabular}

The result obtained by Takalign Bedada the same with his previous result (Tekalign, 2018).

\section{Farmers' Opinion/Perception}

The opinion of those farmers on the sorghum thrasher performance was collected from participants during machine demonstration. The major criteria used by farmers were the machine capacity, threshing efficiency, grain damage, reduce labor, minimize human effort/tiredness and reduce time of thrashing. Therefore, most farmers preferred engine driven sorghum thrasher than traditional thrashing mechanisms

Table 5: Ranks of the varieties based on farmers' selection criteria.

\begin{tabular}{lll}
\hline Implements & $\begin{array}{l}\text { Farmers } \\
\text { rank }\end{array}$ & Reasons \\
\hline Engine driven sorghum thrasher & $1^{\text {st }}$ & $\begin{array}{l}\text { High Machine capacity, high threshing efficiency, low grain } \\
\text { damage, reduce labor, minimize human effort/tiredness and } \\
\text { reduce time of thrashing }\end{array}$ \\
\hline Traditional sorghum thrasher & $2^{\text {nd }}$ & $\begin{array}{l}\text { Low threshing capacity, low threshing efficiency, high grain } \\
\text { damage, maximize human effort/tiredness and increase time } \\
\text { of thrashing }\end{array}$ \\
\hline
\end{tabular}

Table 6: Pair-wise ranking matrix result to rank variety traits

\begin{tabular}{|c|c|c|c|c|c|c|c|c|c|}
\hline $\begin{array}{l}\dot{8} \\
\dot{8} \\
8\end{array}$ & 莺 & 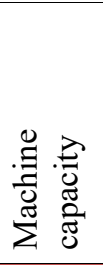 & 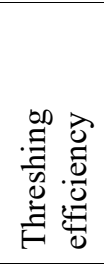 & 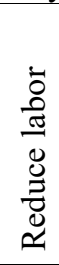 & 兽兽兽 & 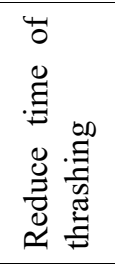 & 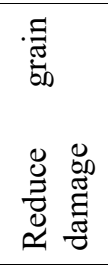 & 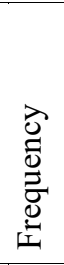 & 䲩 \\
\hline 1 & Machine capacity & & 2 & 1 & 1 & 1 & 1 & 4 & $2^{\text {nd }}$ \\
\hline 2 & $\begin{array}{l}\text { Threshing } \\
\text { efficiency }\end{array}$ & & & 2 & 2 & 2 & 2 & 5 & $1^{\text {st }}$ \\
\hline 3 & Reduce labor & & & & 3 & 3 & 4 & 2 & $4^{\text {th }}$ \\
\hline 4 & $\begin{array}{l}\text { Minimize human } \\
\text { effort/tiredness }\end{array}$ & & & & & 5 & 5 & 1 & $5^{\text {th }}$ \\
\hline 5 & $\begin{array}{l}\text { Reduce time of } \\
\text { thrashing }\end{array}$ & & & & & & 5 & 3 & $3^{\text {rd }}$ \\
\hline 6 & $\begin{array}{l}\begin{array}{l}\text { Reduce } \\
\text { damage }\end{array} \\
\text { grain }\end{array}$ & & & & & & & 0 & $6^{\text {th }}$ \\
\hline
\end{tabular}



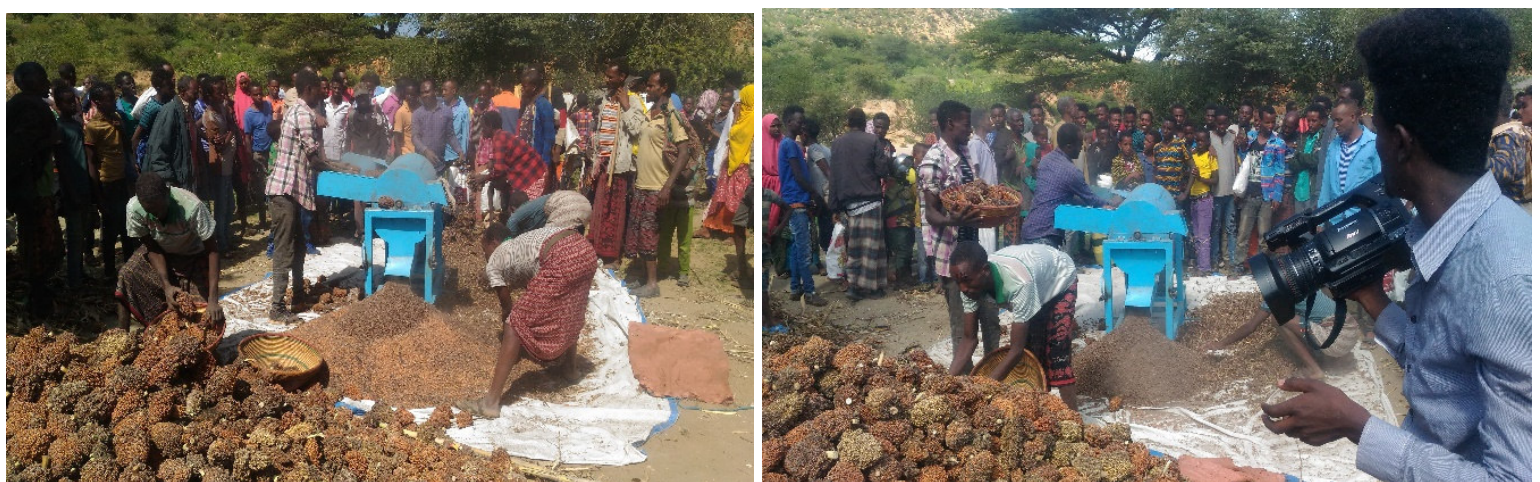

\section{Discussion}

The demonstration of engine driven sorghum thrasher reducing human interaction with the process. The machine has a great future scope for farmers due to its ease of use. The main the advantage is its low operating costs, tame and energy saving. Savings of money resulting from the use of machine can pay for itself within the short period of time.

\section{Conclusion and Recommendation}

The performance of the demonstrated machine, it could be concluded that the Output capacity threshing efficiency and grain damage are 6-8.36 qt/hr.,88.97to97.08\%,less than $1 \%$ respectively .This machine has been fabricated with the use of locally available materials. The machine is simple, less bulky and effective. Grains loss and mechanical visible damage have been very minimal and ease the work and it is better to promote.

\section{References}

CSA 2012: Central Statistics Agency of for Ethiopia 2012

2008. (Central Statistical Authority). Agricultural sample survey, 2008/2009 (2001 E.C) report on area and production for major crops (private peasant holdings, main season), statistical bulletin 446, Addis Ababa, Ethiopia

Food and Agricultural Organization of United Nation, 2010.Sorghum post-harvest operation. Food Security Department

Simonyan 2009, Development of Motorized Stationary Sorghum Thresher. Agricultural Mechanization Asia, Africa and Latin America. VOL.40 NO.3

Simonyan, K. J. 2006. Mathematical modeling of the grain cleaning process in a stationary sorghum thresher. Ph.D Dissertation. Samaru, Nigeria. Ahmadu Bello University. Department of Agricultural Engineering.

Tekalign, B.E. 2018; Improvement of IITA Multi-crop Thresher for Sorghum Threshing. International Journal of pure and Applied Researches: (IJOPAAR), Vol. 2(1); pp. 15-26.

Taylor, J.R.N.,Overview: Importance of Sorghum in Africa: Department of Food Science, UniversityofPretoria,Pretoria0002,SouthAfrica.http://www.afripro.org.uk/papers/Paper01Taylor.pdf Accessed on $30^{\text {th }}$ January, 2010. 